\title{
Quincy Wright: an appreciation
}

\author{
WILLIAM B. BALLIS \\ Department of Political Science, University of Michigan
}

Quincy Wright had a lifelong interest and professional concern in the problem of controlling war, but his unique approach was clearly shaped by his family's scholarly pursuits. His great-grandfather, a mathematician, set up the first actuarial tables in the United States. His father, Philip G. Wright, was an economist with the US Tariff Commission. Quincy's older brother, Sewall, is an internationally known mathematical geneticist and his younger brother, Theodore P., was an internationally renowned aeronautical engineer. Thus all of his immediate family on the male side were scientists, applying mathematical techniques in their fields. Quincy in his way began to look for mathematical applications to the study of war. Karl Deutsch points out in the preface to the second edition of $A$ Study of War (1965) that Wright was one of the first scholars to make use of quantitative data in research on war, adding, "If he were writing A Study of War today, he would probably abbreviate some of the historical and legal arguments and integrate his behavioral and quantitative data into his main text rather than segregate them. ..." However, as a former student of Quincy Wright, I believe that this would vitiate his contribution. While Quincy can be regarded as the founder of modern peace research, which relies heavily on mathematical or quantitative methods of analysis, there still reposes in his work a strong and wide core of immutable legal and historical knowledge which is not only descriptive but also analytical in the tradi- tional sense.

He was, like most of the scholars of his generation, originally trained as a legalist. His academic mentor, James W. Garner of the University of Illinois, was in his day one of the most distinguished scholars in international law, especially the law of war, prize law, etc. Quincy's first important scholarly study was on the relationship of international law to domestic law, particularly its enforcement in the courts. But even before he took up the study of international law, Quincy was very much concerned with the problem of war. A childhood classmate of his once recounted to me Quincy's delivering a high school oration on peace and war about the time of the Second Hague Conference of 1907. Undoubtedly that era of concern over establishing some sort of system to control war had an enormous impact on his formative period. In his international law phase, Quincy's scholarly output was prodigious. It moved into high gear by the time he was thirty, which coincided with the first year of the League of Nations. In the twenties, he began to travel abroad and visit Geneva, The Hague, the Middle East, and the Far East. It was these observations on the scene that probably prompted him to combine his legalistic approach with some of the historical and cultural aspects of current international problems. This period culminated in his impressive and massive scholarly work, Mandates Under the League of Nations.

Beginning in the middle twenties his articles 
turned to the problems of war-its legal status, its elimination through law, the control of aggression, etc.-an interest which continued throughout his life. During this time, Quincy read and reread the history of diplomacy, of war, and of relations between nations. He became in the eyes of his students "a one-man university." When they approached him for a thesis topic, he spurred them to pursue further some aspect of a problem on war and peace which he had pioneered in some journal article. My generation studied with him in the early thirties at the University of Chicago and we identify him primarily with the development of interdisciplinary research on the problem of peace and war. It was he who triggered my interest in working on comparative historical aspects of the doctrines and practices of war in early international law (Ballis, 1937).

The vehicle for the cross-fertilization of graduate students and faculty on the problem of peace and war was primarily Quincy Wright's seminar on law and diplomacy. As a member of this seminar for two years, I well remember the papers not only of his own political science students but also those of historians, psychologists, sociologists, and anthropologists. The dozen or so of us met for two hours every Thursday afternoon. No matter how technical the subject, when a student not in political science was reporting, Quincy would always enrich his comments with considerable additional background to broaden our understanding. He would often read to the seminar his own papers which to a large extent dealt with the problem of war in international law. Sometimes there would be a social evening for the students working on the "Causes of War Project," jointly hosted by his gracious wife, Louise. Also present would be the distinguished historian, Bernadotte E. Schmitt, and equally distinguished economist, Jacob Viner, who worked with Quincy in the early phases of this Project. As stated in his magnum opus, A Study of War (1965, pp. 409-13), many of these research reports grew into doctoral dissertations and some into books. Quincy credits Charles E. Merriam, chairman of the Department of Political Science, for initiating the Causes of War Project. To be sure, Merriam did father the interdisciplinary approach in the social sciences at the University of Chicago and played a key role in establishing the financial and intellectual bases for the project. But Quincy Wright was the director and implementing force and his doctoral students were the most active participants.

The 1930 s represent the most creative period of Quincy's productivity (he was then between his fortieth and fiftieth years). $A$ Study of War went to the publisher in 1941 but was drafted mainly in the late thirties. Paradoxically he finished it during the first battles of World War II and wrote the foreword less than a month before Pearl Harbor. It was in this period that his work laid the basis for what is now called "peace research." But he was not content with being a distinguished scholar in the study of war. Quincy moved out of the library to participation in organizations concerned with the realization of peace. He was prominent in the League of Nations Association, the United Nations Association, and many public societies for the promotion of the study of international relations, such as the American Council of the Institute of Pacific Relations and the American Society of International Law.

Quincy Wright's life was largely dedicated to the idea that war could be controlled through law based on a universal in.ernational system. In one of his last articles, published just before his death, he wrote (Wright, 1969):

I conclude that the foundations for a universal international system are to be found in education to develop more general understanding of the conditions of the present and emerging world, in commitment of peoples and governments to the international system established by the Charter [of the UN], and to the maintenance and development of the existing universal legal and political institutions by appropriate policies and actions. 
Quincy Wright's influence on me, as on hundreds of students who came into contact with him, was that of the master teacher. His classes and conferences were a joy to his students. He would awe, interest, and delight his classes, and a conference in his office was a pleasant and profitable experience. Four days a week, at 10:10 AM, he would have his international law and diplomacy class. The first quarter was the law of peace, the second was the law of war, and the third, diplomacy. His lectures were organized and clearly expressed. Since the classes were small and mostly graduates, he often used the Socratic method of instruction-and he truly was a Socrates. After class, four days a week, he had his office "hour." Students would wait in his outer room, which insulated him from the corridor. He gave much time and displayed a warm empathy toward each one. In these conference sessions, he discussed my research with me at great length, always adding, stimulating, and prodding. Whenever I gave him a chapter of my dissertation, I received it back the next day, with his comments scribbled on the margin of each page.

Quincy Wright's daily office "hour" was generally two, from eleven to one. Except for the day on which he held seminar, the afternoons were for his research and the students all understood this. He could be reached on the telephone and was always willing to answer a query, but his massive scholarly output depended on his prodigious hours of work. On Saturday nights I used to attend the Chicago Opera Company performances. Although I would not return to my dormitory room on the campus until long after midnight, there would always be a light in Quincy's office on the Midway side, fourth floor, of the Social Science Research Building. Moreover he would be there most likely on Saturdays and Sundays. Yet he also enjoyed a very full social life with his wife, who had a separate career and a distinguished record of her own in public affairs.

While Quincy spent much time in his office with its huge library, he somehow managed each year to give scores of talks on and off the campus, over the radio on the University of Chicago Roundtable, and to student groups and audiences in the city and suburbs of Chicago. Also active in his profession, he spoke frequently before his professional associations. There his recognition was especially evident. Among other honors, he was president of the American Political Science Association, of the International Political Science Association, of the American Society of International Law, and of the American Association of University Professors.

Quincy Wright reached the top in all branches of his profession and his scholarly accomplishments have been worthily acclaimed, but he has left an additional legacy to his former students. This was the model of the scholar, teacher, and friend, the ideal professor, so to speak, for all his students to strive to approximate. While his encyclopedic knowledge of international law, history, and the social sciences was generously shared with his students, he was also warm, sympathetic, and encouraging to each of them. I never saw him humiliate a student or express criticism in a harsh way. He was in every respect a scholar and a gentlemen.

\section{REFERENCES}

Ballis, William. The Legal Position of War: Changes in Its Practice and Theory from Plato to Vattel. The Hague: Martinus Nijhoff, 1937.

Deutsch, Karl. Preface to the second edition. In Q. Wright, A Study of War. Chicago: University of Chicago Press, 1965.

Wright, Quincy. The foundations for a universal international system (in Italian), Comprendre, $1969,18$.

-... Mandates Under the League of Nations. Chicago: University of Chicago Press, 1930.

—_. A Study of War (2nd edn.). Chicago: University of Chicago Press, 1965. 